\title{
INVESTIGATING THE EFFECTS OF CUTTING PARAMETERS ON THE BUILT-UP-LAYER AND BUILT-UP-EDGE FORMATION DURING THE MACHINING OF AISI 310 AUSTENITIC STAINLESS STEELS
}

\author{
PREISKAVA VPLIVOV PARAMETROV REZANJA NA NASTANEK \\ NAKOPIČENE PLASTI IN NAKOPIČENEGA ROBA MED \\ STRUŽENJEM AVSTENITNEGA NERJAVNEGA JEKLA AISI 310
}

\author{
Mehmet Burak Bilgin \\ Amasya University, Technology Faculty, Dept. of Mechanical Engineering, Amasya, Turkey \\ mehmetburak.bilgin@amasya.edu.tr \\ Prejem rokopisa - received: 2014-10-06; sprejem za objavo - accepted for publication: 2014-11-27
}

doi: $10.17222 /$ mit. 2014.253

\begin{abstract}
This study experimentally investigated the effects of machining parameters on the built-up-layer (BUL) and built-up-edge (BUE) formation and the wear behavior of cutting tools during the machining of the AISI 310 austenitic stainless steel with titanium-carbide cutting tools. Five different cutting speeds $(50,75,100,125$ and 150$) \mathrm{m} / \mathrm{min}$, three feed rates $(0.15,0.20$ and $0.25) \mathrm{mm} / \mathrm{r}$ and two cutting depths $(1.5,2) \mathrm{mm}$ were used as the cutting parameters. The highest accumulation of the BUL and the BUE was observed at a cutting speed of $50 \mathrm{~m} / \mathrm{min}$, a feed rate of $0.15 \mathrm{~mm} / \mathrm{r}$ and a cutting depth of $1.5 \mathrm{~mm}$.

Keywords: built-up edge, built-up layer, machining, stainless steels
\end{abstract}

Ta študija eksperimentalno preučuje vpliv parametrov rezanja na nakopičeno plast (BUL) in nakopičen rob (BUE) ter na vedenje orodja za odrezovanje med struženjem AISI 310 avstenitnega nerjavnega jekla z orodjem iz titanovega karbida. Kot parametri odrezovanja je bilo uporabljeno pet različnih hitrosti $(50,75,100,125 \mathrm{in} 150) \mathrm{m} / \mathrm{min}$, tri hitrosti podajanja $(0,15,0,20$ in 0,25$)$ $\mathrm{mm} / \mathrm{r}$ in dve globini rezanja $1,5 \mathrm{~mm}$ in $2 \mathrm{~mm}$. Največja akumulacija BUL in BUE je bila opažena pri hitrosti rezanja $50 \mathrm{~m} / \mathrm{min}$, hitrosti podajanja $0,15 \mathrm{~mm} / \mathrm{r}$ in globini rezanja $1,5 \mathrm{~mm}$.

Ključne besede: nakopičen rob, nakopičena plast, strojna obdelava, nerjavna jekla

\section{INTRODUCTION}

In the machining process, workpiece materials may adhere to the cutting tool in two ways during the cutting. First, the workpiece becomes welded to the cutting edge, leading to the formation of what is known as a built-up edge (BUE). Second, workpiece materials may distribute and accumulate over a large portion of the cutting tool's rake face, leading to the formation of what is known as a built-up layer (BUL). These situations may arise separately on a cutting edge, or may occur simultaneously.

AISI 310 stainless steels are materials that are commonly used in the manufacturing industry despite their characteristically poor machinability. The most significant machinability problems of stainless steels are the tool smearing and the BUE formation.

Carrilero and Marcos $^{1}$ observed that the tool wear occurs due to a combination of load factors affecting the cutting edge (mechanical, thermal, chemical, abrasive factors). Individually, each load factor can be effective at a certain stage of the tool wear. Generally, the loads do not act separately and as the machining process continues the combined effect of the loads increases gradually.

Carrilero et al. ${ }^{2}$ suggested that, in machining, the tool wear generally determines the tool life, along with the criteria such as the cutting strength or the surface roughness that vary in relation to the cutting parameters.

Korkut et al. ${ }^{3}$ observed that the cutting-tool wear occurs at a faster rate during the machining of stainless steel. By increasing the wear of the cutting edges, a BUE leads to a poor surface finish on a workpiece. While warm chips are led away from the workpiece, they form a continuous wire that wears the cutter and adversely affects the surface of the workpiece. To prevent this, the operator must clean the chips from each machined workpiece, which, in turn, hampers the productivity.

Sanchez et al. ${ }^{4}$ found that certain temperatures, depending on the cutting parameters, might be generated during the machining processes, increasing the occurrence of wear mechanisms (adhesion, oxidation, fatigue, abrasion, diffusion). They also suggested that facilitating the ability of tools to cut within a reasonable period of time is one of the most important topics that should be investigated in the studies conducted on the cutting tool wear.

List et al. ${ }^{5}$ searched the wear behavior in the machining of an aluminum-copper alloy (2024). They suggested that under low cutting conditions, built-up edges form on the tool's rake face and take on the function of the cutting edge. They observed that the continuous sliding 
of BUE fragments between the tool and chips increases the tool wear. They also suggest the use of a large rake angle and a polished tool surface at a low cutting speed as the adhesion mechanism is more mechanical than physical.

Rubio et al. ${ }^{6}$ studied the surface roughness $\left(R_{\mathrm{a}}\right)$ of an AA7050 alloy. They observed that the $R_{\mathrm{a}}$ value of the AA7050 aluminum pieces obtained through the turning process had a certain tendency to decrease with the machined length. They also observed that $R_{\mathrm{a}}$ values slightly increase with the cutting speed. They suggested taking into account that parts of the machined material adhere to the tool on the edge (BUE) and on the rake face (BUL) during the cutting process.

In addition to the mechanical properties of a material, Özçatalbaş and Aydin $^{7}$ discovered that the machining parameters such as the cutting speed, the feed rate, the cutting depth and the cutting-edge geometry are also important to ensure a proper cut.

Gökkaya and Nalbant ${ }^{8}$ investigated the effects of different cutting speeds, built-up layers and built-up edges on aluminum machining. They suggested that increasing the cutting speed decreased BUL and BUE formations, but did not eliminate them entirely.

Liew and Ding 9 investigated the wear progression in the low-speed end milling of stainless steel. They observed that a strong bonding between an adherent work material and a tool surface can result in the formation of a BUE. When the BUE and the adherent work material on the tool become unstable, they adhere to the underside of the work piece, resulting in a deterioration of the surface finish.

Katuku et al. ${ }^{10}$ investigated the wear, cutting forces and chip characteristics of austempered ductile iron under finishing conditions. Using cutting speeds ranging from $50 \mathrm{~m} / \mathrm{min}$ to $800 \mathrm{~m} / \mathrm{min}$, they observed that, at cutting speeds lower than $150 \mathrm{~m} / \mathrm{min}$, the abrasion wear was the main wear mechanism. They suggested that, at these cutting speeds, the fragmentation of chips and the instability of the BUE controlled the dynamic cutting forces.

Thakur et al. ${ }^{11}$ studied the machinability of Inconel 718 during high-speed turning. They used cutting speeds within the range of 40-60 $\mathrm{m} / \mathrm{min}$; however, the BUE formation was not observed at the aforementioned machining parameters.

Chattopadhyay et al. ${ }^{12}$ studied the wettability and machinability of pure aluminum for uncoated and coated carbide cutting-tool inserts. They observed that a large built-up edge was formed on the uncoated and all the coated carbide inserts, excluding diamond. They concluded that the flank-wear measurement confirms that the diamond-coated tool is superior.

Neugebauer et al. ${ }^{13}$ investigated the velocity effects in metal forming and machining processes. They suggested that the adherent material may, assuming a low cutting velocity, form built-up edges, while at high speeds, a thin flow layer with extremely high shear deformations tends to develop.

Zhou et al. ${ }^{14}$ investigated the surface damage in the high-speed turning of Inconel 718. They found that, at a low feed rate, the tendency to form built-up edges is also higher than at a higher feed rate, due to an increase in the size of the plastic-deformation area at the interface of the tool and the workpiece.

Khan et al. ${ }^{15}$ investigated the tool wear/life in the finish turning of Inconel 718. They found that, at the lowest cutting speed $(150 \mathrm{~m} / \mathrm{min})$, a severe grooving and a built-up-edge (BUE) formation were observed on the wear-scar micrographs in all the experiments. They observed that as the cutting speed increased to $300 \mathrm{~m} / \mathrm{min}$, the presence of the grooving and BUE diminished.

Gomez-Parra et al. ${ }^{16}$ investigated the built-up-edge and built-up-layer formations in the turning of aluminum alloys. They suggested that the changes in the BUL and BUE took place and the formation mechanisms were related to the changes observed in the roughness profile of the machined pieces and evaluated through the average surface roughness, $R_{\mathrm{a}}$. They confirmed that the BUE growth is responsible for a decrease in $R_{\mathrm{a}}$; this is due to the fact that a higher BUE thickness can be related to a lower value of the tool-position angle and, thus, to a lower value of the maximum height of the cutting finger on the workpiece surface.

In this study, the machining of the AISI 310 austenitic stainless-steel material, i.e., the CNC turning machining under dry conditions was performed using a titanium-carbide cutting tool at five different cutting speeds, three different feed rates and two different cutting depths $(1.5 \mathrm{~mm}, 2 \mathrm{~mm})$ as the cutting parameters. The aim for this study was to establish the ideal cuttingcondition parameters by determining the wear tendencies of the cutting edge and the effects of the cutting speed, the feed rate, and the cutting depth on the built-up-layer and built-up-edge formations with the aid of a scanning electron microscope (SEM).

\section{MATERIALS AND METHODS}

A spectral analysis of the AISI 310 stainless-steel material used in the experiments was performed using a $11814 / 00$ optic emission spectrophotometer. The chemical composition of the test samples is indicated in Table $\mathbf{1}$.

All the test samples were extracted by cutting a single-sized part so that they all consisted of the same crucible material. Thus, it was ensured that the test samples had the same physical and chemical characteristics. The sample dimensions used in the tests are shown in Figure 1.

During the study, the cutting parameters indicated in Table 2 were applied to the test samples listed in Table 1. Throughout the experiments, a TC 35 Johnford CNC turning machine with a Fanuc control unit was used according to the parameters indicated in Table 2. The 
Table 1: Chemical composition of AISI 310 austenitic stainless steel (w/\%)

Tabela 1: Kemijska sestava AISI 310 avstenitnega nerjavnega jekla (w/\%)

\begin{tabular}{|c|c|c|c|c|c|c|c|}
\hline $\mathrm{C}$ & $\mathrm{Si}$ & $\mathrm{Mn}$ & $\mathrm{P}$ & $\mathrm{S}$ & $\mathrm{Cr}$ & $\mathrm{Mo}$ & $\mathrm{Ni}$ \\
\hline$<0.0050$ & 0.3885 & 2.173 & $>0.0960$ & 0.0344 & 17.67 & 0.2983 & 14.71 \\
\hline $\mathrm{Al}$ & $\mathrm{Cu}$ & $\mathrm{Nb}$ & $\mathrm{Ti}$ & $\mathrm{V}$ & $\mathrm{Fe}$ & \\
\hline 0.0145 & 0.0806 & $<0.0050$ & $<0.0010$ & 0.0457 & 61.70 & \\
\hline
\end{tabular}

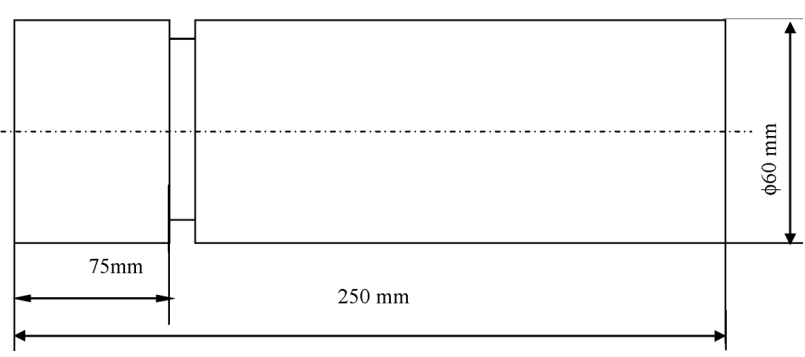

Figure 1: Dimensions of the samples used in the experiments Slika 1: Dimenzije vzorcev, uporabljenih pri preizkusih

attachment of the test samples to the turning machine and their machining are schematically represented in Figure 2.

Due to dry cutting being recommended by a cutter's catalogue, the cutting fluid was not used during the machining of the test samples. A titanium-carbide-covered SNMG 120408-MS US735-shaped cutting edge, with an ISO M30 certification, recommended for austenitic stainless steel by the Mitsubishi company, a cutting-tool manufacturer, was used, along with its matching SSBCR112525 tool holder, for the machining of the test samples. The choice of the cutting parameters to be used during the tests was determined by taking into consideration the manufacturing company's data, prepared according to ISO 3685 . These cutting parameters are listed in Table 2. Different machining parameters such as the cutting speed in addition to the feed rate and the cutting depth were used for each sample.

The optimum cutting speeds were $80-120 \mathrm{~m} / \mathrm{min}$ for the chosen cutting edge. To observe the results obtained with the cutting speeds below and above the recommended cutting speed, cutting speeds of $50-150 \mathrm{~m} / \mathrm{min}$ were also included in the tests. The feed rate and the cutting depth suitable for a radius $0.8 \mathrm{~mm}$ cutting-tool

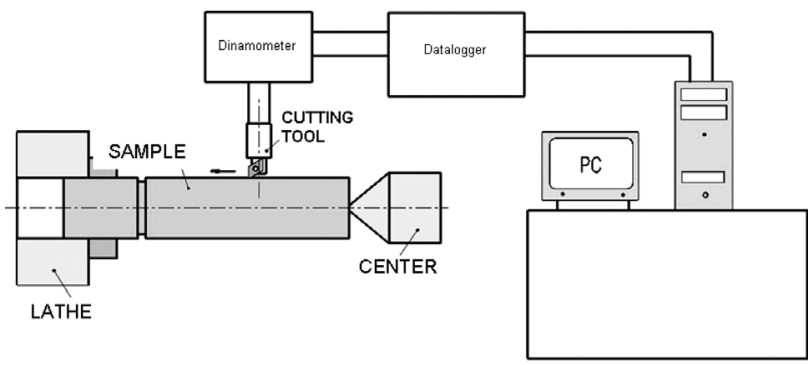

Figure 2: Attachment of the test samples and measurement of cutting forces

Slika 2: Namestitev preizkusnih vzorcev in merjenje sil pri rezanju edge were determined based on the ISO 3685 reference values.

To determine the wear tendency of the cutting edge resulting from the machining performed with different cutting parameters, a different cutting edge was used for each test. Thus, an attempt was made to elucidate the contribution of each parameter to the built-up-layer and built-up-edge formations.

Table 2: Cutting parameters used in machining experiments Tabela 2: Parametri rezanja pri preizkusih strojne obdelave

\begin{tabular}{|c|c|c|c|c|c|c|c|}
\hline $\begin{array}{c}\text { Expe- } \\
\text { riment } \\
\text { No. }\end{array}$ & $\begin{array}{c}V / \\
(\mathrm{m} / \mathrm{min})\end{array}$ & $\begin{array}{c}f / \\
(\mathrm{mm} / \mathrm{r})\end{array}$ & $a / \mathrm{mm}$ & $\begin{array}{c}\text { Expe- } \\
\text { riment } \\
\text { No. }\end{array}$ & $\begin{array}{c}V / \\
(\mathrm{m} / \mathrm{min})\end{array}$ & $\begin{array}{c}f l \\
(\mathrm{~mm} / \mathrm{r})\end{array}$ & $a / \mathrm{mm}$ \\
\hline 1 & 50 & \multirow{5}{*}{0.15} & \multirow{5}{*}{1.5} & 16 & 50 & \multirow{5}{*}{0.15} & \multirow{5}{*}{2} \\
\hline 2 & 75 & & & 17 & 75 & & \\
\hline 3 & 100 & & & 18 & 100 & & \\
\hline 4 & 125 & & & 19 & 125 & & \\
\hline 5 & 150 & & & 20 & 150 & & \\
\hline 6 & 50 & \multirow{5}{*}{0.20} & \multirow{5}{*}{1.5} & 21 & 50 & \multirow{5}{*}{0.20} & \multirow{5}{*}{2} \\
\hline 7 & 75 & & & 22 & 75 & & \\
\hline 8 & 100 & & & 23 & 100 & & \\
\hline 9 & 125 & & & 24 & 125 & & \\
\hline 10 & 150 & & & 25 & 150 & & \\
\hline 11 & 50 & \multirow{5}{*}{0.25} & \multirow{5}{*}{1.5} & 26 & 50 & \multirow{5}{*}{0.25} & \multirow{5}{*}{2} \\
\hline 12 & 75 & & & 27 & 75 & & \\
\hline 13 & 100 & & & 28 & 100 & & \\
\hline 14 & 125 & & & 29 & 125 & & \\
\hline 15 & 150 & & & 30 & 150 & & \\
\hline
\end{tabular}

To determine the cutting forces involved in the chip formation during the machining performed with the CNC turning machine, a KISTLER 9257B piezoelectric-crystal-based dynamometer was used. To assess the wear rate, the wear and the smearing behavior of the cutting edges were examined using the JEOL JSM 6060 LV scanning electron microscope (SEM).

\section{DISCUSSION}

In this study, machining was performed at five different cutting speeds, three different feed rates and two different cutting depths using a titanium-carbide-covered tool. The analysis of the cutting edges with scanning microscopy revealed that the highest BUE formation occurred on the samples machined at lower cutting speeds. Hence, despite the use of different cutting parameters, the SEM images obtained for a cutting speed of $50 \mathrm{~m} / \mathrm{min}$ and with the highest amounts of the built-up edge and built-up layer were evaluated. The scanningelectron-microscopy images of the BUE formed on the 

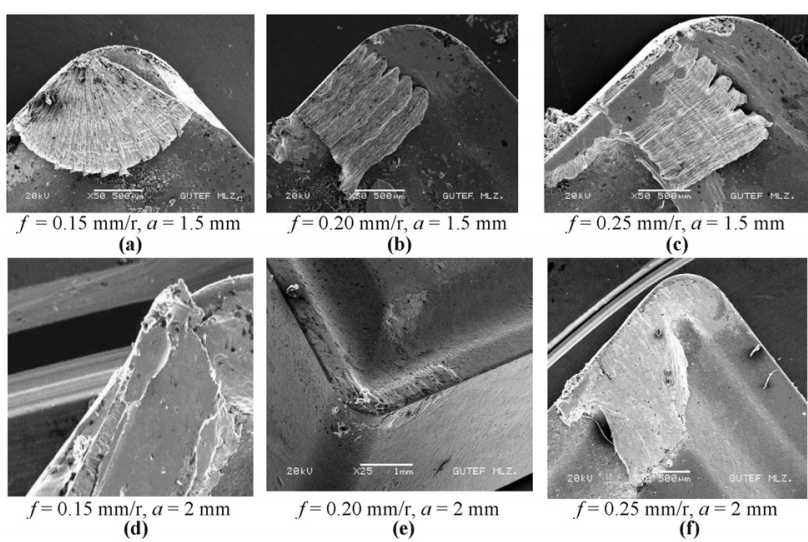

Figure 3: SEM images of BUE and BUL formed on the radius of the cutting tool used for the experimental sample at a cutting speed 50 $\mathrm{m} / \mathrm{min}$

Slika 3: SEM-posnetki BUE in BUL, ki nastajajo na radiusu rezilnega orodja, uporabljenega pri vzorcu, s hitrostjo rezanja $50 \mathrm{~m} / \mathrm{min}$

cutting edge with the test samples machined at the cutting speed $50 \mathrm{~m} / \mathrm{min}$ are provided in Figure 3. A uniformly distributed BUE can be seen in Figure 3, while a non-uniformly distributed BUE can be seen in other figures.

It is possible to claim that within the experimental ranges, the feed rate and cutting depth were not as signi-
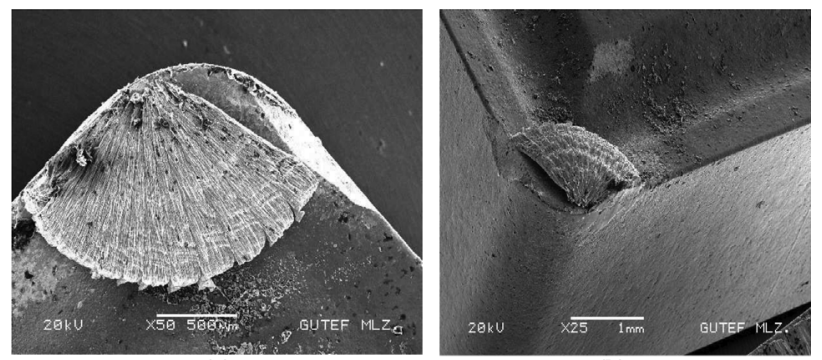

(a)

(b)

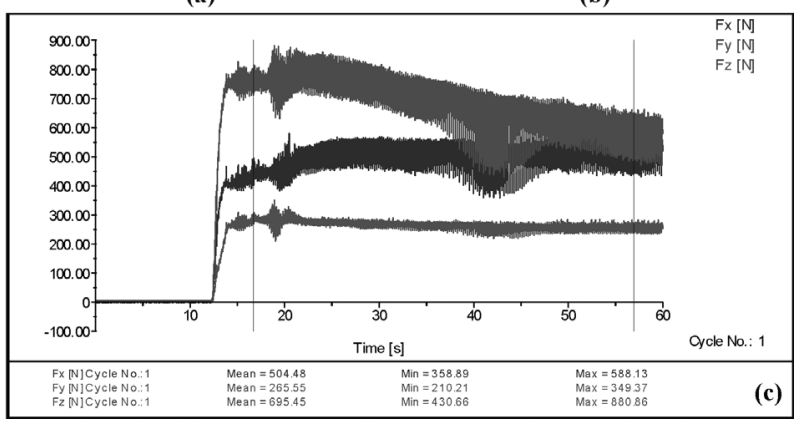

Figure 4: a), b) SEM images and c) a cutting-force diagram of the cutting tool under the machining conditions of $50 \mathrm{~m} / \mathrm{min}$ cutting speed, $0.15 \mathrm{~mm} / \mathrm{r}$ feed rate and $1.5 \mathrm{~mm}$ cut depth

Slika 4: a), b) SEM-posnetka in c) diagram sile rezanja rezalnega orodja pri strojni obdelavi: hitrost rezanja $50 \mathrm{~m} / \mathrm{min}$, hitrost podajanja $0,15 \mathrm{~mm} / \mathrm{r}$ in globina rezanja $1,5 \mathrm{~mm}$

Table 3: Wear of the cutting edges used in the experiments

Tabela 3: Obraba rezilnih robov pri preizkusih

\begin{tabular}{|c|c|c|c|c|c|c|c|c|c|}
\hline $\begin{array}{l}\text { Expe- } \\
\text { riment } \\
\text { No }\end{array}$ & $\begin{array}{c}V / \\
(\mathrm{m} / \mathrm{min})\end{array}$ & $\begin{array}{c}f / \\
(\mathrm{mm} / \mathrm{r})\end{array}$ & $\begin{array}{c}a / \\
\mathrm{mm}\end{array}$ & Evaluation & $\begin{array}{c}\text { Expe- } \\
\text { riment } \\
\text { No }\end{array}$ & $\begin{array}{c}V / \\
(\mathrm{m} / \mathrm{min})\end{array}$ & $\begin{array}{c}f / \\
(\mathrm{mm} / \mathrm{r})\end{array}$ & $\begin{array}{c}a / \\
\mathrm{mm}\end{array}$ & Evaluation \\
\hline 1 & 50 & \multirow{5}{*}{0.15} & \multirow{5}{*}{1.5} & $\begin{array}{l}\text { There is a smooth BUE at the } \\
\text { edge }\end{array}$ & 16 & 50 & \multirow{5}{*}{0.15} & \multirow{5}{*}{2} & $\begin{array}{l}\text { There is a notch at the cutting } \\
\text { edge because of the BUE }\end{array}$ \\
\hline 2 & 75 & & & $\begin{array}{l}\text { There is very little wear at the } \\
\text { edge }\end{array}$ & 17 & 75 & & & The edge is clean \\
\hline 3 & 100 & & & $\begin{array}{l}\text { The edge is clean; there is very } \\
\text { little accumulation at the far end }\end{array}$ & 18 & 100 & & & $\begin{array}{l}\text { The edge is clean, there is a } \\
\text { crush inside }\end{array}$ \\
\hline 4 & 125 & & & The edge is clean & 19 & 125 & & & $\begin{array}{l}\text { The edge is clean, there is a } \\
\text { little accumulation inside }\end{array}$ \\
\hline 5 & 150 & & & $\begin{array}{l}\text { There is a little notch at the } \\
\text { edge }\end{array}$ & 20 & 150 & & & The edge is clean \\
\hline 6 & 50 & \multirow{5}{*}{0.20} & \multirow{5}{*}{1.5} & There is a BUE & 21 & 50 & \multirow{5}{*}{0.20} & \multirow{5}{*}{2} & $\begin{array}{l}\text { There is crater erosion at the } \\
\text { edge; there is a crush inside }\end{array}$ \\
\hline 7 & 75 & & & There is a notch at the far end & 22 & 75 & & & $\begin{array}{l}\text { There is notching at the side } \\
\text { surface; there is a crush inside }\end{array}$ \\
\hline 8 & 100 & & & $\begin{array}{l}\text { There is very little BUE at the } \\
\text { side surface }\end{array}$ & 23 & 100 & & & $\begin{array}{l}\text { The edge is clean; there are } \\
\text { residues }\end{array}$ \\
\hline 9 & 125 & & & The edge is clean & 24 & 125 & & & $\begin{array}{l}\text { There are notches at the edge } \\
\text { and side surface }\end{array}$ \\
\hline 10 & 150 & & & The edge is clean & 25 & 150 & & & The edge is clean \\
\hline 11 & 50 & \multirow{5}{*}{0.25} & \multirow{5}{*}{1.5} & $\begin{array}{l}\text { Plenty of BUE; there is a notch } \\
\text { at the far end }\end{array}$ & 26 & 50 & \multirow{5}{*}{0.25} & \multirow{5}{*}{2} & $\begin{array}{l}\text { There is an accumulation at the } \\
\text { side surface }\end{array}$ \\
\hline 12 & 75 & & & $\begin{array}{l}\text { There is a little BUE at the side } \\
\text { surface }\end{array}$ & 27 & 75 & & & $\begin{array}{l}\text { The edge is clean; there is a } \\
\text { crush inside }\end{array}$ \\
\hline 13 & 100 & & & $\begin{array}{l}\text { There is some BUE at the side } \\
\text { surface }\end{array}$ & 28 & 100 & & & $\begin{array}{l}\text { The edge is clean; there is a } \\
\text { crush inside }\end{array}$ \\
\hline 14 & 125 & & & $\begin{array}{l}\text { There is a BUE line at the far } \\
\text { end }\end{array}$ & 29 & 125 & & & $\begin{array}{l}\text { The edge is clean; there is a } \\
\text { crush inside }\end{array}$ \\
\hline 15 & 150 & & & The edge is clean & 30 & 150 & & & $\begin{array}{l}\text { The edge is clean; there is a } \\
\text { crush inside }\end{array}$ \\
\hline
\end{tabular}


ficant as the cutting speed for the formation of the built-up edge and built-up layer. However, when the images in Figure 3 are examined, it can be seen that the feed rate and the cutting depth also had a slight effect on the BUE and BUL, in addition to the cutting speed. It can be stated that increasing the cutting depth may slightly increase the BUE and BUL, while increasing the feed rate may lead to a slight decrease in the BUE and BUL.

The SEM images of the formations observed on the cutting tool under the machining conditions of the cutting speed $50 \mathrm{~m} / \mathrm{min}$, feed rate $0.15 \mathrm{~mm} / \mathrm{r}$, and cutting depth $1.5 \mathrm{~mm}$ are provided in Figure 4. As can be seen in Figure 4, if a built-up layer forms on the rake face of the cutting tool, the built-up edge forms uniformly along the main cutting edge and the tool-nose radius progresses towards the cutting tool's rake face. It was noted that the cutting forces increased when the BUE also increased. This is demonstrated in a two-dimensional image shown as Figure 4a and a three-dimensional image of Figure 4b. The cutting-force diagram is given in Figure 4c.

The images obtained with scanning electron microscopy for the other cutting edges used in the machining of the test samples are not provided. Instead, an evaluation of all the cutting parameters of the cutting edges is provided in Table 3. When the results obtained with the SEM for the cutting edges used during the test are examined, a decrease in the cutting-tool wear corresponding to a decrease in the smearing tendency is observed, as seen in Figures 5 and 6. In relation to the decrease in the smearing tendency, a decrease in the cutting-tool wear can also be observed when Figures 5 and $\mathbf{6}$ are examined. In the tests conducted with the cutting speed of $50 \mathrm{~m} / \mathrm{min}$, the feed rate of $0.15 \mathrm{~mm} / \mathrm{r}$ and the cutting depth of $1.5 \mathrm{~mm}$, the wear of the cutting tool was observed to decrease as the cutting speed increased, despite the presence of a notch in the cutting edge.

In Figure 5, it is possible to see the traces of the built-up-layer and built-up-edge formations on the cutting tool after the machining at $75-100 \mathrm{~m} / \mathrm{min}$.

In Figure 6, the built-up layer can be observed once again on the rake face of the cutting tool. On the other

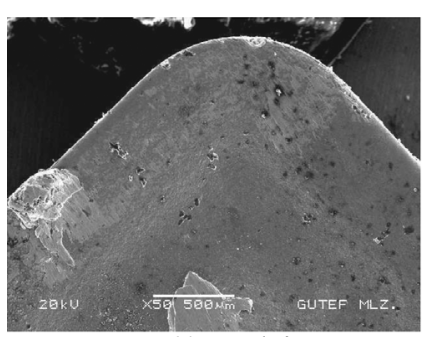

(a) $75 \mathrm{~m} / \mathrm{min}$

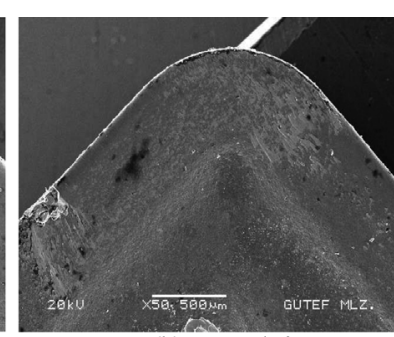

(b) $100 \mathrm{~m} / \mathrm{min}$
Figure 5: Cutting-edge radius used for the test samples machined at cutting speeds of: a) $75 \mathrm{~m} / \mathrm{min}$ and b) $100 \mathrm{~m} / \mathrm{min}$

Slika 5: Radius rezilnega roba pri vzorcu, obdelanem s hitrostjo rezanja: a) $75 \mathrm{~m} / \mathrm{min}$ in b) $100 \mathrm{~m} / \mathrm{min}$ hand, a built-up edge formed on the main cutting edge. At cutting speeds of $125 \mathrm{~m} / \mathrm{min}$ and $150 \mathrm{~m} / \mathrm{min}$, smaller built-up layers and built-up edges formed. However, the built-up edge extended to the cutting tool's rake face due to an accumulation. A decrease in the BUE, corresponding to a decrease in the cutting strength, can be seen in Figure 6c.

It was observed that the cutting condition affected the formation of the built-up layer and built-up edge. The built-up-layer and built-up-edge thicknesses were observed to be on an increase up to the critical level as long as the machining was performed. Following this increase, the built-up edge was identified as being plastically deformed and extending towards the cutting-tool surface. For this reason, the previous built-up layer was covered and remained below the new layer. The builtup-layer and built-up-edge formations disrupt the geometry of the cutting tool. Disrupting the tool geometry and efficiency causes a workpiece to have a rough surface and reduced efficiency. The lowest surface quality was achieved with the cutting speed of $50 \mathrm{~m} / \mathrm{min}$, the $0.25 \mathrm{~mm} / \mathrm{d}$ feed rate, and the cutting depth of $2 \mathrm{~mm}$, which resulted in a surface-roughness value $\left(R_{\mathrm{a}}\right)$ of 5.75 $\mu \mathrm{m}$. The formation of a BUE, particularly on the chip roots, contributed to the increase in the surface roughness.

In the assessments that were performed, the sizes of the built-up layer and built-up edge formed at the cutting speed of $50 \mathrm{~m} / \mathrm{min}$ were observed as being larger than the built-up layer and built-up edge formed at the cutting speed of $150 \mathrm{~m} / \mathrm{min}$. At the $150 \mathrm{~m} / \mathrm{min}$ cutting speed, no built-up edge was identified in the environs of the toolnose radius that extended towards the rake face. This
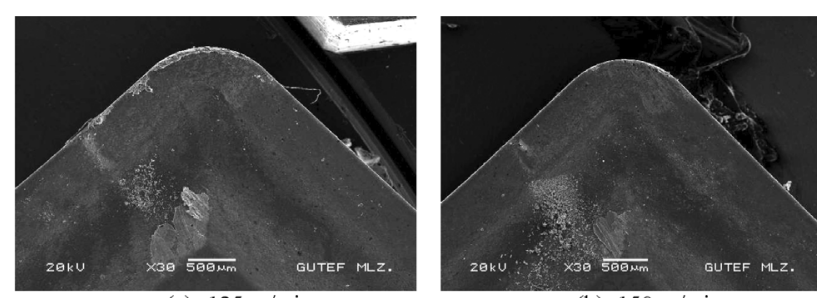
(a) $125 \mathrm{~m} / \mathrm{min}$ (b) $150 \mathrm{~m} / \mathrm{min}$

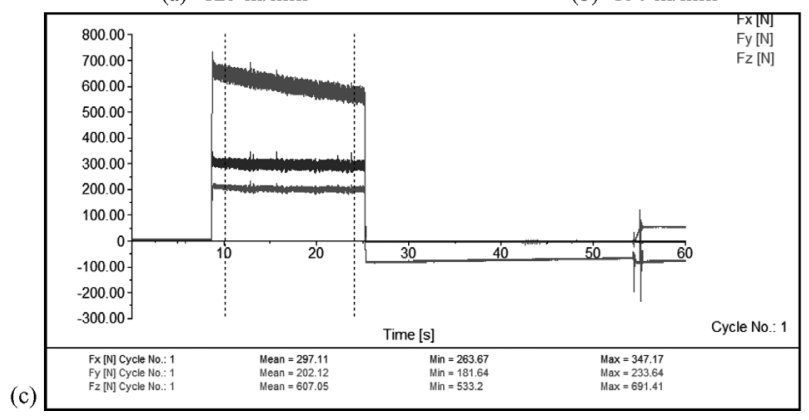

Figure 6: Cutting-edge radius used for the test samples machined at cutting speeds of: a) $125 \mathrm{~m} / \mathrm{min}$, b) $150 \mathrm{~m} / \mathrm{min}$ and c) cutting-force diagram

Slika 6: Uporabljeni radij rezilnega orodja pri obdelavi vzorca s hitrostjo rezanja: a) $125 \mathrm{~m} / \mathrm{min}$, b) $150 \mathrm{~m} / \mathrm{min}$ in c) diagram sile rezanja 
situation demonstrated that the cutting speed is an important parameter for the formation of a built-up edge.

The causes of this decrease can be explained with the effects of the factors such as the ease of deformation processes associated with the increasing temperatures at high cutting speeds, the ease of deformation of the workpiece material around the cutting edge and tool-nose radius, and the plastic flow formed at high temperatures.

The temperatures generated by the increase in the cutting speed result in soft layers that create a plastic flow. This, in turn, prevents the formation of built-up layers and built-up edges. Based on the observations from the experiments performed, it can be stated that cutting speeds above $100 \mathrm{~m} / \mathrm{min}$ are necessary to prevent the formation of built-up layers and built-up edges.

\section{CONCLUSIONS}

Cutting tools were examined under a SEM to determine the effects of machining parameters on the formation of built-up layers and built-up edges on the cuttingtool surfaces during machining processes. The results obtained within the experimental ranges are provided below:

- The effects of the feed rate and cutting depth on the formation of built-up edges and built-up layers were not as significant as the effect of the cutting speed.

- built-up edge formed on the main cutting edge of the cutting tool.

- The built-up-edge formation along the main cutting edge of the cutting tool did not affect the characteristics of the main cutting edge.

- The wear of the cutting tools was observed mainly at low cutting speeds, particularly at $50 \mathrm{~m} / \mathrm{min}$. It is possible to claim that an increasing cutting speed leads to a decrease in the cutting wear.

- A built-up layer formed on the rake face of the cutting tool.

- A built-up edge formed at a low cutting speed of 50 $\mathrm{m} / \mathrm{min}$ was observed to progress from the environs of the tool-nose radius towards the surface of the rake face.

- In the machining of the AISI 310 austenitic stainless steel, the built-up-layer and built-up-edge formations decreased as the tested cutting speeds increased. However, higher speeds could not entirely prevent the formations of built-up layers and built-up edges.

- It can be asserted that, during the machining of the AISI 310 austenitic stainless steel with titaniumcarbide cutting tools, cutting speeds higher than 100 $\mathrm{m} / \mathrm{min}$ are necessary to prevent the built-up-layer and built-up-edge formations, as well as the cutting-tool wear.

\section{REFERENCES}

${ }^{1}$ M. S. Carrilero, M. Marcos, On the Machinability of Aluminium and Aluminium Alloys, J of Mech Behav of Mater, 7 (1996) 3, 179-191, doi:10.1515/JMBM.1996.7.3.179

${ }^{2}$ M. S. Carrilero, R. Bienvenido, J. M. Sanchez, M. Alvarez, A. Gonzalez, M. Marcos, A SEM and EDS insight into the BUE and BUL difference in the turning processes of AA2024 Al-Cu Alloy, Int J of Mach Tool and Manuf, 42 (2002) 2, 215-220, doi:10.1016//S08906955(01)00112-2

${ }^{3}$ I. Korkut, M. Kasap, I. Çiftci, U. Şeker, Determination of optimum cutting parameters during machining of AISI 304 austenitic stainless steel, Mater Design, 25 (2004), 303-305, doi:10.1016/j.matdes. 2003.10.011

${ }_{4}^{4}$ J. M. Sanchez, E. Rubio, M. Alvarez, M. A. Sebastian, M. Marcos, Microstructural characterization of material adhered over cutting tool in the dry machining of aerospace aluminium alloys, $\mathrm{J}$ of Mater Process Tech, 164-165 (2005), 911-918, doi:10.1016/j.matprotec.2005. 02.058

${ }^{5}$ G. List, M. Nouari, D. Gehin, S. Gomez, J. P. Manaud, Y. Le Petitcorps, F. Girot, Wear behavior of cemented carbide tools in dry machining of aluminium alloy, Wear, 259 (2005), 1177-1189, doi:10.1016/j.wear.2005.02.056

${ }^{6}$ E. M. Rubio, A. M. Camacho, J. M. Sanchez-Sola, M. Marcos, Surface roughness of AA7050 alloy turned bars analysis of the influence of the length of machining, J of Mater Process Tech, 162-163 (2005), 682-689, doi:10.1016/j.matprotec.2005.02.096

${ }^{7}$ Y. Özçatalbaş, B. Aydin, Mekanik özellik ve kesme geometrisinin AA2014 alaşiminin işlenebilme özelliklerine etkileri, Gazi Üniversitesi Mühendislik Mimarlik Fakültesi Dergisi, 21 (2006), 21-27

${ }^{8}$ H. Gökkaya, M. Nalbant, Kesme hizinin yiğinti katmani ve yiğinti talaş oluşumu üzerindeki etkilerinin SEM ile incelenmesi, $J$ of the Faculty of Eng and Arch of Gazi Uni, 22 (2007) 3, 481-488

${ }^{9}$ W. Y. H. Liew, X. Ding, Wear progression of carbide tool in lowspeed end milling of stainless steel, Wear, 265 (2008), 155-166, doi:10.1016/j.wear.2007.09.003

${ }^{10}$ K. Katuku, A. Koursaris, I. Sigalas, Wear, cutting forces and chip characteristics when dry turning ASTM grade austempered ductile iron with PCBN cutting tools under finishing conditions, J of Mater Process Tech, 209 (2009), 2412-2420, doi:10.1016/j.matprotec. 2008.05.042

${ }^{11}$ D. G. Thakur, B. Ramamoorthy, L. Vijayaraghavan, Study on the machinability characteristics of superalloy Inconel 718 during high speed turning, Mater Design, 30 (2009) 5, 1718-1725, doi:10.1016/ j.matdes.2008.07.011

${ }^{12}$ A. K. Chattopadhyay, P. Roy, A. Ghosh, S. K. Sarangi, Wettability and machinability study of pure aluminium towards uncoated and coated carbide cutting tool inserts, Surf Coat Tech, 203 (2009), 941-951, doi:10.1016/j.surfcoat.2008.08.047

${ }^{13}$ R. Neugebauer, K. D. Bouzakis, B. Denkena, F. Klocke, A. Sterzing, A. E. Tekkaya, R. Wertheim, Velocity effects in metal forming and machining processes, CIRP Annals-Manuf Tech, 60 (2011), 627-650, doi:10.1016/j.cirp.2011.05.001

${ }^{14}$ J. M. Zhou, V. Bushlya, J. E. Stahl, An investigation of surface damage in the high speed turning of Inconel 718 with use of whisker reinforced ceramic tools, J of Mater Process Tech, 212 (2012), 372-384, doi:10.1016/j.matprotec.2011.09.022

${ }^{15}$ S. A. Khan, S. L. Soo, D. K. Aspinwall, C. Sage, P. Harden, M. Fleming, A. White, R. M'Saoubi, Tool wear/life evaluation when finish turning Inconel 718 using PCBN tooling, 5th CIRP Conference on High Performance Cutting, Procedia CIRP, 1 (2012), 283-288, doi:10.1016/j.procir.2012.04.051

${ }^{16}$ A. Gomez-Parra, M. Alvarez-Alcon, J. Salguero, M. Batista, M. Marcos, Analysis of the evolution of the Built-Up Edge and Built-Up Layer formation mechanisms in the dry turning of aeronautical aluminium alloys, Wear, 302 (2013), 1209-1218, doi:10.1016/j.wear. 2012.12.001 